Article

\title{
Measuring the Performance in Creative Cities: Proposal of a Multidimensional Model
}

\author{
Margarida Rodrigues and Mário Franco * 1 \\ CEFAGE-UBI Research Center, Department of Management and Economics, University of Beira Interior, \\ Estrada do Sineiro, 6200-209 Covilhã, Portugal; mmmrodrigues@sapo.pt \\ * Correspondence: mfranco@ubi.pt
}

Received: 4 October 2018; Accepted: 26 October 2018; Published: 2 November 2018

\begin{abstract}
Cities are essential vectors for economic and sustainable development worldwide, as a consequence of globalization and the recent economic, financial, social, and environmental crises. In this connection, urban creativity, intelligence, and sustainability are inseparable dimensions of those cities, since when they are in harmony with the networks from which they originate, they can be predictors of their improved performance. Therefore, this study aims to propose a conceptual and multidimensional model for cities that shows their implicit dimensions and general indicators so that their performance can be measured in a holistic way. This study also forms some implications for theory and practice. Finally, the conclusion shows the study's contribution and limitations together with suggestions for future research.
\end{abstract}

Keywords: cities; sustainability; indicators; performance; creativity; multidimensional model

\section{Introduction}

Given the phenomenon of globalization and the recent economic, financial, and social crisis, the view of cities' role in global economic growth has undergone a paradigmatic change, in which their tangible resources have become associated with intangible ones as a crucial differentiating factor to overcome the decline and economic stagnation that has been experienced by many cities in Europe and the rest of the world. This means that we have a new generation of cities [1] possessing an intelligent philosophy/ideology that is centered on creating bridges with creativity to solve the problems they face, and also focused on the integration of cultural, social, environmental, and economic dimensions as a whole [2]. This intelligent philosophy was shown by Neirotti et al. [3] and Albino [4] in their definitions of a 'smart city'. These authors argued that the smart city concept is no longer limited to the diffusion of information communication technology (ICT), but includes the city's networked infrastructure as it is related to political efficiency and social and cultural development, a business-oriented urban development, an emphasis on social inclusion, social capital, and natural environment, and the emergence of creative cities that relies on community-based and private sector initiatives, living labs, and social entrepreneurship. Consequently, these cities intend to be innovative/creative [5] and adopt strategies aiming for their sustainable economic, social, and environmental development [4], in an intelligent way [6-8], in order to improve the quality of life provided to their inhabitants [4]. However, for the effective and intelligent operationalization of these strategies, information and communication technologies (ICT) must be an integral part of them $[9,10]$, since their incorporation transforms the different ways that city residents live and work, and also contributes to improved collaboration processes (networks) and the use of institutions to stimulate sustainability [2].

Due to the ambiguity existing in the concepts of the typology of cities, it is worth noting that in this theoretical study, the definitions adopted are as follows. (1) Creative cities are those that advocate socio-cultural, economic, and political changes [11], and they are characterized by diversity, openness, 
tolerance, the existence of a creative class, and high cultural dynamism [12-14]. (2) Intelligent cities are based on a participatory governance that is embedded in an urban ecosystem supported by information and communication technologies [15], and which invests in social and human capital and owns resources to improve the quality of life of its citizens and promote their economic growth [16]. (3) Sustainable cities as a broader concept integrates social development, economic development, environmental management, and urban governance, which refers to the management and investment decisions taken by municipal authorities in coordination with national authorities and institutions [17]; this means that in this study, it is assumed that these settings are integrated holistically.

On the other hand, rapid urban development has caused social and environmental concerns, besides economic ones, that jeopardize human well-being and sustainability [18], which are reflected in the European Union's 2020 Strategy (intelligent, sustainable, and inclusive growth). This means that the design of today's cities must have the pillars of urban creativity, intelligence, and sustainability, which is understood as a link between so-called creative cities, intelligent cities, and sustainable cities. Various authors have shown this link between the different city typologies $[2,15,19,20]$; they argued that intelligent cities are also creative due to how residents are involved in them. This includes the sharing of knowledge, culture, entrepreneurship, and social relations, and requires focusing on innovation and the integration of technology with culture [2].

It has been widely discussed in the academic and political domains that intelligent cities and creative cities must be sustainable. Therefore, all city actors must understand the importance of urban sustainability and act cohesively as a whole [21], have the capacity to attract talented human capital (creative class/creativity) to build an intelligent platform (ICT, governance) and stimulate growth based on multiple, interconnected, and dynamic activities, implying that when business, technology, culture, and creativity interact, this generates innovations and contributes to urban sustainability [22,23].

In addition, the formation of networks is a factor that is included in the competitive advantage of today's cities, particularly creative cities, since cities function as intangible spaces of innovation, knowledge, sharing, learning, and collaboration [2]. The same author considers that networks induce cities' growth and simultaneously turn them into an intelligent, cultural space stimulating the development of new ideas (creativity/innovation) and entrepreneurship in its various forms (for example, urban).

Based on these arguments, the recommended approach to cities should be multi-disciplinary [24], where the paradigmatic change occurring in the role that they play in building a sustainable society, based on creativity, innovation, technology, and networks, has directed the interest of the academic community and the political class worldwide toward the study of creative, intelligent, and sustainable cities [25]. However, in the extensive literature on these cities, gaps in need of research remain, specifically in relation to measuring their performance based on a conceptually designed model as a methodological instrument. Corroborating the lack of this type of study, Malecki [26] showed the need to define indicators to measure cities' performances. Pain et al. [27] concluded that there is still a shortage of studies associating cities' connections/networks with their performance. Lee, Hancock and Hu [28] claimed it is essential to elaborate a scale for cities' different dimensions to measure their performance.

More recently, Bibri and Krogstie [29] concluded strongly on the absence of integrated/holistic conceptual models of cities and the respective index to assess their performance and contributions. No less important are the gaps that have been identified in relation to the many existing indices for cities, i.e., it is crucial to compile existing indices and converge them in a single index [30,31]. In the same line of thought, Priano and Guerra [32] concluded that the process of measuring cities requires the standardization of existing models, and Huovila et al. [33] stated the clear need for a holistic and integrating model and index to measure cities' performances.

Supported by the gaps identified justifying the relevance of studying the performance of creative cities and how this can be measured by intelligence and sustainability, without neglecting the essence of creativity that supports them and the network influence, this study aims to present a proposal of a multidimensional design for current creative cities (CCC) and the respective indicators that are generally 
used, despite being scattered over various types of indexes, in order to measure their performance. To achieve this objective, the following research question is formulated: What are the dimensions underlying the current multidimensional and holistic vision of creative cities? Therefore, this study's contribution is related to the proposed model, including the premises defined so that cities' present and future performances are integral and supported by the pillars of creativity, intelligence, and sustainability, which are measured by the positive effects of networks.

\section{Literature Review}

\subsection{Cities' Performance}

Cities' performances should be measured in all their dimensions from a multidimensional and holistic perspective $[25,34]$, since current cities have a fundamental role in the global economy as places of connectivity (networks), creativity, and innovation associated with social and economic progress, culture, diversity, and the environment [35]. A city's performance includes dimensions that are inherent to their tangible and intangible resources, as argued by Anthopoulos [36].

Furthermore, the measurement of a city's performance has undergone a transformation that is inherent to the paradigmatic change in the vision of the role that they play in economic growth. However, this does not mean the traditional variables of measurement should be discarded, such as for example gross domestic product (GDP), the inflation rate, or the unemployment rate [37]. However, these variables should be considered intermediary and as complementing citizens' current interests to reach other social and economic objectives, as explained in that report. Therefore, it is perceived that cities ought to face the challenge to grow sustainably and intelligently, encourage creativity, and satisfy their residents, aiming to show high tangible and intangible performance $[38,39]$. So, the determinant dimensions for this urban transformation, particularly in Europe, are society, the economy, governance, transport, and the land [40]. Cities' performance is the result of integrating policies indicating appropriate directions for economic growth and urban development, as in the case of Munich, which adopted the pillars of creativity, intelligence, and sustainability [41].

Caragliu, del Bo, and Nijkamp [16] also concluded that cities' urban performance depends not only on their physical capital, but also increasingly on their human and social capital to improve their competitive advantage. Camagni [42] also argued that cognitive capital (cities' competences and their capacity to change), relational capital (openness, tolerance, cooperation, interaction, and synergies) and environmental capital (transport, quality of life and lifestyle, cultural legacy) should be fundamental variables for current cities. This means that today's cities should be innovative in order to be able to attract new firms and talent. To stimulate existing opportunities, entrepreneurship should be an effective strategy, allowing the attainment of the desired economic growth reflected in these cities' improved performance [16].

In addition, it is important that these premises are supported by a growth strategy [16] that reflects the intelligent organization of tangible and intangible facilities/amenities strengthened by the inclusion of ICT, creativity, and innovation. Conjugated with cities' urban design, this promotes their economic viability (performance) [3,34], network connections, and sustainability [34].

In this context, the literature on cities' design/dimensions is extensive and includes numerous conceptual models with different dimensions and indices/indicators to measure the performance of different city typologies, such as creative [11-13,24,43-47], intelligent [1,3,16,46-49], sustainable [50-54], creative and intelligent [55], and intelligent and sustainable [21,56-58].

This dispersion is justified by the complexity of managing a city holistically [4], despite all of them aiming to improve citizens' quality of life [59]. However, the most studied dimensions are ICT, the economy, mobility, environment, people, governance, sustainability, creativity, and open networks [46,60-66], whose points in common are network infrastructure, creative activities, inclusion, urban growth, and a sustainable environment. Inherent to each of these are various proxies that allow the measurement of their specific weight in cities' performance through appropriate measurement indices [4]. 
In other words, this performance is assessed by a set of indicators, which are understood as a tool, and so, the United Nations (67) recommended the implementation of concrete measures of this in cities, in order to demonstrate their progress [67] with simultaneous monitoring. This means that an analysis of the indicators used lets political decision-makers identify cities' opportunities/threats, so that their performance can be continuously and sustainably improved [68].

Given the multiple indices for measuring cities' performance in its many dimensions, Hartley, Potts and MacDonald [69] compiled the most commonly used general indicators, as shown in Figure 1.

\begin{tabular}{|c|c|c|}
\hline Culture & Entertainment & Tourism \\
\hline Creative results & Employment & \\
\hline Cultural capital & Participation & \\
\hline Places & Resources & Amenities \\
\hline Habitability & Amenities & \\
\hline Transport & Accessibility & \\
\hline Openness & Tolerance & Diversity \\
\hline Globalization & Networks & \\
\hline Human capital & Talent & Education \\
\hline Social capital & Commitment & Support \\
\hline Governance & Regulation & \\
\hline Business activity & Economy & \\
\hline Entrepreneurship & Innovation & $\begin{array}{l}\text { Research \& } \\
\text { Development }\end{array}$ \\
\hline ICT & $\begin{array}{l}\text { Research \& } \\
\text { Development }\end{array}$ & \\
\hline Environment & Ecology & \\
\hline
\end{tabular}

Figure 1. Sub-dimensions of cities, adapted from Hartley et al. [69].

In addition, the compilation of the indicators is shown in Figure 1, according to the studies by Giffinger et al. [46] and Carli et al. [70]. There are many others studies that are also important ones, but these are not mentioned in this study. Thus, Giffinger et al. [46] identified six characteristics of smart cities according to the broad literature on this topic, which are: economy, people, governance, mobility, environment, and living. These six characteristics were considered to be the relevant group characterizing a smart city. They can be broken down into 31 relevant factors, which reflect the most important aspects of every smart characteristic. Finally, every factor of a smart characteristic has been defined empirically through a group of corresponding indicators. In total, 74 indicators were defined and used for operationalizing and aggregating the relevant factor. Therefore, these authors empirically studied 70 European cities. Carli et al. [71] carried out an empirical study in Italy (city of Bari) to evaluate and manage the performance of smart cities, and also developed a framework for classifying the performance indicators of a smart city. This author used two dimensions: (1) the degree of objectivity of observed variables, and (2) the level of technological advancement for data collection. However, other studies [72,73] recognize the limitations of composite indices and focus on sub-dimensions per se (e.g., energy, governance). Finally, Carli, Dotoli, and Pellegrino [70] proposed the use of an analytical hierarchy process (AHP) multi-criteria decision-making technique 
for application in the smart metropolitan city context, with the aim of analyzing the sustainable development of energy, water, and environmental systems, through a set of objective performance indicators. Specifically, the 35 indicators defined for the Sustainable Development of Energy, Water, and Environment Systems Index framework were used.

On the other hand, the sub-dimensions that are shown in Figure 1 are included in the dimensions of creativity, intelligence, and urban sustainability, and to summarize, it is argued that cities are intelligent places whose performance is assessed based on their creative class and their level of education, environment, mobility, and technology [16], and so are considered critical nodes (networks) to apply the creative changes required [2] to stimulate social cohesion and economic productivity, as well as conserve natural resources, their historical identity, and their culture [30].

In this context, creativity is an alternative pillar of sustainable economic growth [74], and creative cities provide multiple opportunities for this [75], since they promote innovations and solutions to current urban problems [76,77], namely regarding improving productivity/performance [12,75]. The next section presents the dimensions of creative cities of the $21^{\text {st }}$ century-current creative cities (CCC) - and the indicators generally used by academics and political decision-makers to measure their performance.

\subsection{Dimensions and Indicators of Performance in Current Creative Cities (CCCs)}

\subsubsection{Creativity}

This dimension became popular in the United States following the study by Florida [12,13], who introduced the theory of the creative class (creative, talented individuals) as indispensible for cities' economic prosperity. Recently, Romero-padilla et al. [78] argued that this contributes to the theory of economic growth, as it stimulates the creation of new creative ideas. In this context, the vast literature on creative cities is persuasive with regard to creativity having become an emblematic solution to growing urban development [21], as a consequence of the various problems caused by the phenomenon of globalization (e.g., the decline and stagnation of some cities) [21,79]. Clear examples of creative cities are Silicon Valley, Bavaria Valley (Bavaria), Silicon Glen (Scotland), Silicon Saxony (Dresden) [80], Barcelona, San Francisco, Glasgow [81], Rotterdam, and Amsterdam [11]. These examples refer to different urban areas; however, studies that elaborated on these $[11,80,82]$ showed that cities can be reinvented by adopting a cultural economy [82], local governments can increase the chance that urban creativity emerges by providing the appropriate framework conditions [80], and it is important to assess the success factors of different cities [11].

Implicit to creativity is tolerance, talent, and technology (3Ts), which were defined by Florida [12] as determinants to attract, retain, and stimulate the creative class in cities and create a favorable climate for this. Such an environment is characterized by socio-cultural diversity [12-14], openness to entrepreneurial ideas, and the technology to achieve high economic performance, whose driver is creativity from the perspective of the creative economy $[12,13,83]$. Here, the cities themselves promote the necessary changes [11] for this to generate added value [81] and raise entrepreneurship and innovation [84].

In this domain, creative cities show an intelligent strategy by joining their economic and urban strategies with culture [85], i.e., with creative industries as drivers to create economic values [2,79], including high technology, cultural, and media firms [57]. Consequently, the association between culture, the economy, and creativity ensures that cities' cultural and historical legacy is not neglected [2, 79]. Another benefit of this association is related to stimulating urban partnerships/networks and new dynamics in cities [86], which attracts the creative class and entrepreneurs [2]. In this way, these creative industries join together in creative clusters in cities, as urban socio-cultural spaces $[76,87]$ that attract creative talents and new investment [12]. From another perspective, various authors [2,8890] explained that these clusters are used to stimulate urban regeneration in cities through generally being located geographically in redeveloped infrastructure (e.g., London, Berlin, and Barcelona) [91], 
which means that they are considered urban, creative environments [59], being operationalized by urban entrepreneurship and the maximization of local networks [92,93].

Explicitly and according to network theory [94-96], local networks are a fundamental strategy for cities, allowing the formation of formal links between all of the actors that are involved in their space [97], and consequently, have a positive effect on cities' improved economic performance $[27,98,99]$, on intercity and intracity knowledge transfer/sharing [100] and on better access to information [101]. However, these benefits result from creative cities being rooted in the interaction between culture, communication, and networks with the aim of stimulating regeneration [92]. Therefore, new forms of connectivity should be established between public and private bodies and citizens, such as living labs [102] and public-private partnerships that promote urban entrepreneurship as a form of creativity in cities [2,103], with the example of reference being Amsterdam [2,104].

Summarizing, in the creativity dimension, certain factors determining performance are implicit in CCCs; this has been subject to measurement by various authors and public and private entities/institutions by defining creativity indices that enable the improvement of the strategies and policies defined and implemented in cities in the European Union, according to the 2020 Strategy. Table 1 presents indicators of creativity.

Table 1. Creativity index.

\begin{tabular}{clc}
\hline Sub-Dimension & \multicolumn{1}{c}{ General Indicator } & \multicolumn{1}{c}{ Source } \\
\hline \multicolumn{1}{c}{ Culture } & $\begin{array}{l}\text { Places of culture and facilities } \\
\text { Cultural participation and attractiveness }\end{array}$ & {$[16,46,69,82,105-109]$} \\
\hline Creative economy & $\begin{array}{l}\text { Creativity and employment } \\
\text { Intellectual property and innovation }\end{array}$ & {$[46,69,79,105,106,108]$} \\
\hline Favourable climate & $\begin{array}{l}\text { Human capital and education } \\
\text { Openness, tolerance, and trust } \\
\text { Local and international connections } \\
\text { Governance }\end{array}$ & {$[16,46,69,105,109-115]$} \\
\hline
\end{tabular}

The above indicators reflect the importance of joining creative class theory $[12,13]$ with networks and the influence of creative individuals in their formation [116].

\subsubsection{Intelligence}

For Ratten [2], the dimension of intelligence is present in the vector of creativity, i.e., in CCCs. This author explained that intelligent cities are also designated as creative cities, due to the ways that citizens are involved in them, through the sharing of knowledge, culture, entrepreneurship, and social relations $[15,19,20]$, as well as their focus on innovation and integrating technology with culture [2]. Supported by these conclusions, Boulton, Brunn, and Devriendt and others $[62,79,117,118]$ argued that the creative class can be used intelligently, and so cities' intelligence covers human capital, social capital, relational capital, education, environmental concerns, and evidently ICT as a means to provide political and economic efficiency [119] and social, cultural, and urban development [8]. In addition, in CCCs, creativity, innovation [2], networks, creative clusters, technology absorption [120], amenities, social equity, and quality of life [55] are axes of intelligence that cannot do without technology (ICT) [121].

In this context, cities' vitality and economic growth is the reflection of individuals' creative capacity to adapt to technological progress [2,79], since connectivity in cities, at various levels, is only possible by integrating ICT in the urban scenario [122]. As a sub-dimension of intelligence, ICT is a driver of improved city performance [123], as it is understood to stimulate innovation and the nature of social, environmental and economic relationships [124,125]. In addition, ICT promotes the formation of public-private partnerships, with community involvement, in order to stimulate entrepreneurship in its various forms and network cooperation/formation [123,126-128] 
and e-governance [129]. Finally, ICT allows cities' urban infrastructure to be increasingly intelligent, which is another benefit of adopting intelligent vectors in cities [130].

No less important is the role of ICT in CCCs' form of governance, which appears in the form of communication, the relation with residents, and the transfer of knowledge between all of the actors that are involved, i.e., e-governance [129]. Consequently, the use of ICT means the policies implemented for cities' economic growth (performance) must stimulate governance that is leading and visionary as well as strategic [49].

Therefore, it is perceived that ICT is a sub-dimension of intelligence with the potential to increase global economic growth in the present and future, supported by the positive performance of cities worldwide as a consequence of their new holistic vision [34]. Given the benefits that ICT transfers to CCCs, various conceptual models include this as a major pillar so that they can become intelligent and improve their performance in the long-term $[3,45,46,48,64,131]$. Nevertheless, whatever the model of intelligence that is adopted, there is a need to monitor and measure it in cities so that they can become more efficient operationally in terms of performance [71]. Many cities' capacity for prosperity is dependent on integrating ICT in their urban development strategy [132].

Given the importance of measuring this dimension, various indices/indicators have emerged allowing this to be carried out, and the most commonly used ones are presented in Table 2.

Table 2. Intelligence index. ICT: information and communication technology.

\begin{tabular}{ccc}
\hline Sub-Dimension & General Indicator & Source \\
\hline \multirow{2}{*}{ Governance } & Implementation & {$[68,109]$} \\
& Strategy & {$[108,109,133] ;$} \\
& Democratic & {$[46,106,110,134-137]$} \\
\hline \multirow{2}{*}{ ICT infrastructure and networks } & Telecommunications & {$[34,138]$} \\
& Transport & {$[138]$} \\
& Energy & {$[138]$} \\
& Environment & {$[138]$} \\
ICT accessibility & Sensors & {$[138]$} \\
& Tariffs & {$[34]$} \\
Use of ICT & Mobility & {$[34,46,106]$} \\
& Of technology & {$[34,46,106,139]$} \\
Vitality & Individual & {$[16,34,46,106,133,138]$} \\
\hline
\end{tabular}

This set of indicators shows that urban openness, innovative services, networks, urban proactiveness, integration of infrastructure, and governance [28] have ICT in common [29], as they are all directed toward creating bridges with creativity and solving residents' current problems [2,140]. It has also been pointed out that ICT makes intelligent governance viable [141], as well as the adoption of collaboration/partnership processes to take advantage of diversity and create efficient cities that are pleasant to live and work in with quality [140]. Consequently, this considerably improves CCCs' intelligent performance.

It should also be noted that ICT produces a large number of data in the city, so it is important not to overlook the phenomenon of BIG DATA and OPEN DATA [142], which is compatible with intelligence [16], sustainability [29,132], and creativity [2].

\subsubsection{Urban Sustainability}

Urban sustainability is another dimension of cities that has been widely researched, since it represents the interconnection between physical, social, and economic axes $[6,143]$. Nevertheless, exponential urban growth has created social and environmental concerns that jeopardize that sustainability [18], due to 
major migratory flows to cities [144], which requires structural, process, and cultural changes in governing institutions [145].

Urban sustainability means the balance between economic, social, and environmental pillars [29,146-148], and its implementation in cities reflects their leaders' competences [56] for an improved quality of life associated with growth to take place efficiently [149]. However, Cavalcanti [150] considered that there is a fourth pillar named cultural sustainability, mirroring the ability to conserve places' cultural identity and allowing the introduction of new values to support socio-economic transformations. Summarizing, urban sustainability includes four vectors: (1) economic, (2) social, (3) environmental, and (4) cultural.

Furthermore, this sustainability should be intelligent, i.e., its approach should include the use of ICT, since this facilitates solutions to current concerns that are inherent to the challenge of making cities sustainable [151-154], specifically because ICT has been recognized as determinant in promoting performance in the context of the circular economy [155]. Consequently, the aim is for cities' economy to be efficient and sustainable in the present and the future, through adopting the circular economy, in order to maximize the use of human capital and minimize that of natural resources [156-160].

So, the applicability of the four pillars of sustainability in cities and in their socio-economic contexts is seen to be multifaceted and complex [161-163], which means that urban sustainability affects the balance between environmental protection and integration, economic growth and urban regeneration, and social equity and justice in cities [132].

In addition, and as networks are crucial for competitive advantage [164] and for the exchange of symbolic knowledge $[165,166]$, it is evident that at the regional level, these are an important factor in promoting sustainable development, which is clear in the model of regional integration defined by the European Union (EU). This model includes formal and informal structures as well as coordination and collaboration processes, and so this begins to be a priority for governments (inter-networks and intra-networks) [167]. Sharma and Kearins [168] suggested that through the collaboration process, the actors that are involved obtain a better understanding of the economic, social, and environmental questions that affect their regions' sustainability, and therefore alter their behavior to obtain added legitimacy. However, the type of strategic behavior adopted by cities to respond to the challenge to improve the performance and quality of life involves different actors, priorities, resources, and policies [102], according to their geographical context and urban morphology [169].

Summarizing, joining sustainability with creativity [170,171], ICT [170-176], and networks [177] stimulated by the existence of a collaborative community, such as living labs $[178,179]$ and urban entrepreneurship [180] gives rise to cities' improved performance.

The great complexity involved in urban sustainability justifies an assessment of the weight of this dimension in cities' performance, through indices. Therefore, Table 3 shows a set of indicators that are relevant for that measurement, which are to be followed through by application at a more detailed level of these and implicit proxies. However, it is emphasized that the following indices/indicators only refer to economic, social, and environmental sustainability, since those referring to the axes of ICT (intelligence) and creativity/culture (cultural sustainability) are presented in Sections 2.2.1 and 2.2.2, respectively. 
Table 3. Index of urban sustainability.

\begin{tabular}{ccc}
\hline Sub-Dimension & General Indicator & Source \\
\hline \multirow{2}{*}{ Economic } & Competitiveness & {$[16,34,46,106,108,115,136,181-184]$} \\
& Economic activity & {$[34,46,106,134,136,184]$} \\
\hline \multirow{2}{*}{ Social } & Population & {$[46,106,108,115,136,184]$} \\
& Education & {$[34,46,106,108,115,136,181,184]$} \\
& Inclusion and cohesion & {$[46,108,184]$} \\
Environmental & Social infrastructure & {$[34,46,106,108,136,184]$} \\
& Emission and production of atmospheric pollution & {$[34,46,106,108,181]$} \\
& Circular economy & {$[185,186]$} \\
& Urbanism & {$[34,106,114,115,136,181,187]$} \\
\hline
\end{tabular}

Table 3 above shows that the premises of the general indicators that are most commonly used to measure cities' sustainability; these include the improved well-being of citizens and society as a whole, which implies that urban planning and management should be integral, in order to take advantage of the benefits in the present and future [188,189].

\subsection{Proposal of a Conceptual and Multidimensional Model for CCCs}

Supported by the literature review, it is argued that cities must be perceived holistically. In other words, cities should have creative/favorable environments for the interaction of talented people in order to obtain cultural synergies, which are articulated with the co-creation of economic value and with a catalyst effect to promote urban regeneration, and thereby achieve urban sustainability [84]. In addition, Caragliu et al. [16] explained that it is crucial to add to these driving forces the benefits of intelligence, so that cities are attractive and encourage entrepreneurship.

In this context, CCCs have creativity by focusing on the role of culture as a catalyst, which means that the restoration and regeneration of cultural heritage is a determinant leading the economy, by stimulating synergies, networks, and partnerships between all of the stakeholders, in order to gain an economic return in the present and future [171]. It is also leading intelligence by supporting cycles of value exchange through the process of the circular economy and through participative and creative governance [171] organized around technological resources [3].

So, responding to the objective and the research question defined, Figure 2 presents a model of a multidimensional and holistic design for CCCs. This model shows that networks promote CCCs' holistic performance, whereby flows generated by creativity, intelligence, and urban sustainability have a joint effect on continuously improving performance.

This coherence between the three dimensions of CCCs must be reflected in cities' strategies and policies. This means that political decision-makers must not neglect the influence of their tangible (e.g., basic social infrastructure of education, security, and protection) and intangible assets (e.g., collaboration processes, natural resources, citizenship, cultural heritage, identity, cultural values, individual and collective competences), which should be managed and benefited from in a balanced way so that their return is reflected in cities' competitive advantage and performance. This means that this study positions itself in a holistic view of the current creative cities sustained in previous studies [48]. These studies defended the performance measurement of these cities as an integrated and comprehensive composite indicator for creativity, intelligence, and urban sustainability. Consequently, the model proposed in Figure 2 allows this balance and its reflection in the three-dimensional economic growth of CCCs. 


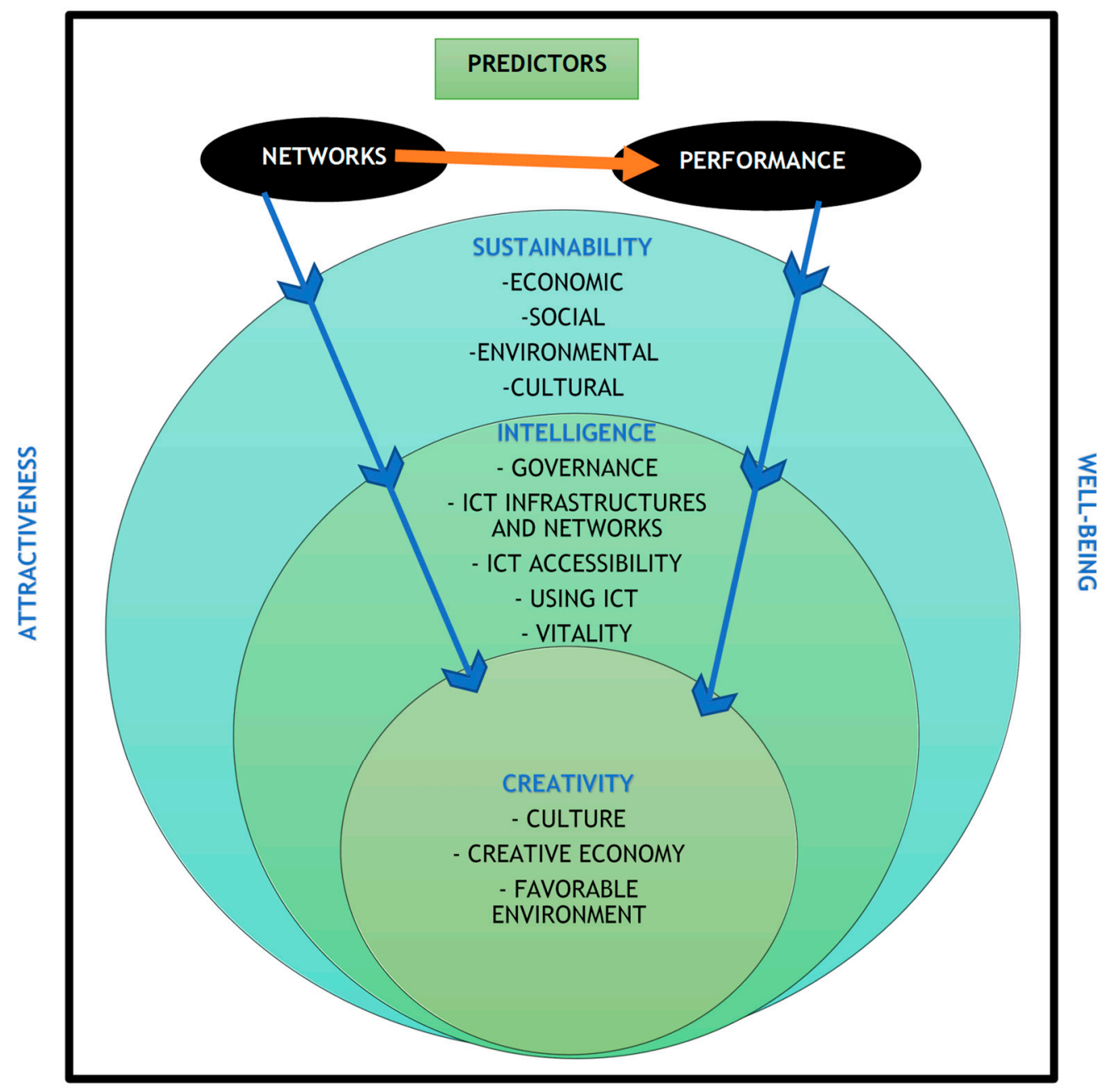

HAPPINESS

Figure 2. Design of a multidimensional model for current creative cities (CCCs) (source: elaboration own).

Briefly, the current paradigm around cities does not allow creativity and intelligence to be ignored in cities' present strategies, and so urban sustainability should be measured by culture, by the creative economy and by a climate that favors them, where this connectivity and integration stimulates and promotes network formation and urban entrepreneurship, which in turn improves sustainability in social, economic, and environmental terms, and consequently cities' economic growth. Implicitly, this model means the adoption of a participative and intelligent model of governance interlinked with culture and the urban buzz, and in this way promotes urban regeneration as a driver of high CCC performance. In addition, this model shows the social capital that values the relations/connections between people, since these provide the formation of social networks in the cities [190], which is also important in CCCs [191].

\subsection{Contextual Application of the Proposal Model for CCCs}

The present proposal model is a contribution to the scientific debate about the performance of CCCs. Similar to much recent argument, it is important to consider the geographical location of cities, their population density, their cultural identity, and even their spatiality, as characteristics that influence this performance. 
In this sense, several studies [190-197] have suggested that the CCC discourse should take into account the specific characteristics of cities per se, particularly if they are considered small, inland, rural, or large urban cities. Lorenzen and Andersen [194] applied this theory in small cities and pointed out that the theory of the creative class has to be adapted to the context of these cities to their geographical and cultural characteristics, since there are different types of cities. In future studies on CCCs, creative class mobility in small urban cities and rural cities are important [198]. Finally, in a recent study by Rastghalam et al. [196], it was suggested to formulate a proposal for rural cities to become creative cities and, thus to improve the balance between urbanized space and rurality.

On the other hand, the pertinence of the balance between geographic contexts with different characteristics implies that urban policies are reviewed and also affect rural areas, in addition to urban ones, since the former are also able to offer the class and ambitious amenities that creatives need [198]. In addition, these policies, such as those directed at creativity, should be flexible, since the specificities of the places are decisive for their success or not, such as cultural heritage, for which reason the role of culture in the urban environment and its contribution to the economic growth in cities is essential in CCCs [198].

Given this scenario, our model can be linked to a real context (i.e., a specific country and cities), for example, applying our proposal presented here in Portugal. The justification for this geographical context of application meets the literature referenced above, given that coastal towns and cities have greater population density, and so there is an imbalance in the population's distribution and the facilities provided. So, Portugal is divided into seven large regions (Nuts II): north, center, and the metropolitan areas of Lisbon, Alentejo, Algarve, Azores, and Madeira. In turn, the metropolitan areas are sub-divided in 25 territorial units (Nuts III), and these territorial units comprise 308 (N) towns/local authorities. Consequently, this heterogeneous distribution of the population implies that the policies that are associated with cities' creativity, intelligence, and sustainability have different impacts and performances. The largest cities are Lisbon, Sintra, Vila Nova de Gaia, Porto, Cascais, Loures, Braga, Matosinhos, Amadora, Almada, Oeiras, Gondomar, Seixal, Guimarães, and Odivelas. In view of these specificities of Portugal, the measurement of performance through the proposed model allows us to identify the differences between Portuguese cities, taking into account their location and population.

It should be noted that this model is the theoretical support for identifying the general, specific indicators and proxies for each of the dimensions/sub-dimensions that are most commonly used in the scientific community. This identification will later be adapted to the Portuguese context and to the available data. In the light of these circumstances, the data collection process will begin with the determination of the data available in the various sources in Portugal, followed by their coupling with the identified dimensions, sub-dimensions, and indicators. It should be noted that the data collected will be guided by quality, reliability, and comparability as inseparable characteristics of a good indicator [199]. Aware of the imperative of meeting the requirements of a good indicator, it will still be necessary to transform the absolute data obtained into relative data, in order to allow subsequent comparisons between cities, irrespective of their size.

Of course, these are all assumptions of a purely qualitative character. Moreover, this prescriptive value of our conceptual model can support political decision-makers and local governments to evaluate their politics. Up to now, proposals for holistic conceptual models have hardly been susceptible to scientific scrutiny; empirical verification is almost non-existent in the literature. Therefore, what remains is the empirical test of the approach and the investigation of the quantitative impact of the defined dimensions/sub-dimensions that affect the performance of CCCs by building a composite index; so, this scrutiny should be addressed by collecting information to expand from the conceptual model presented here. However, data collection involves the use of several data sources to be compiled and worked by the researcher to achieve the purposes of this study.

\section{Final Considerations and Contributions}

Since the 1970s, cities have been faced with economic and social stagnation and decline, with many of them suffering the negative effects of a fall in population and dilapidated infrastructure and 
buildings. In this context, a paradigmatic change is found in the vision of the role and future of cities, stimulated by the phenomenon of globalization. This new vision meant that cities' economic and political importance grew quickly, and that political decision-makers understood that these help to solve their everyday problems of a social, economic, and environmental nature. This vision is shared by the Networked Society City Index [34], where the aim is for cities to become more inclusive, safe, resilient, creative, intelligent, and sustainable, supported by the use of ICT and network connectivity, and by adopting a more sustainable consumption model: circular economy.

The first contribution of this theoretical study lies in presenting a model of a multidimensional design for CCCs based on a wide-ranging view including creativity, intelligence, and urban sustainability at the same level, with their dissemination being joint and inseparable. This model incorporates the objectives and premises defined by the EU's 2020 Strategy EU (intelligent, sustainable, and inclusive growth) to combat the negative externalities of exponential urban development and migratory flows to large urban areas. Finally, the proposed model fills the gaps identified in the literature, since it compiles the individual models developed for each of its dimensions, preceded by compilation of the relevant general indicators to measure cities' performance, besides considering networks as an instrument predicting this. It is also shown that urban sustainability can be promoted through cities' intelligence and creativity.

The second contribution lies in the originality of integrating networks in the model as one of cities' endogenous characteristics that is understood as a determinant factor for increased performance. These networks are considered a city's intangible assets, where the city presents its main node. Residents, being creative and entrepreneurial, are its core, and they can also be conceived around public-private-people partnerships (4Ps). For example, living labs are open innovation networks that can be associated with urban entrepreneurship and directed to vitalizing cities' urban environments.

It is also highlighted that the proposed model shows cities' tangible and intangible resources as endogenous characteristics, and the city amenities that are the starting point for formulating and implementing strategies aiming to stimulate growth by obtaining synergies and the co-creation of added value for the city and its current and future residents.

Furthermore, this model allows some practical considerations to be made, i.e., cities cannot aspire only to grow economically, as traditional economic indicators are out of date. This means that cities' intangible nature is increasingly becoming the path to their holistic growth, by allowing the returns obtained to be re-invested in other critical areas of the city, which generates a cycle of continuous growth with its own resources generated by creativity and stimulated by intelligence, whose benefits can contribute to urban sustainability.

As with any study, this one is not without limitations. The first concerns the theories used, with some subjectivity being implicit in the choice, since others could have been used. The second limitation concerns the indices/indicators presented, with the knowledge that many more could be used. The model here proposed does not include mobility as a dimension. However, it is seen as a crucial axis. For some authors [200], performance must be measured by an index of mobility apart from other dimensions, which reports the third limitation and an area of potential future research. It should be noted once again that the general indicators here presented are the ones that stood out most from the literature reviewed in this study; however, we are aware that others could be used. This selection of indicators is a fourth limitation, since it involves the subjectivity of the researchers. Finally, another limitation concerns the unavailability of a single official database when the unit of analysis is the cities, which suggests that the investigator himself will have the ability to turn this lack of aggregate information.

Despite this being a topical issue, some fields still require future study. In this connection, a suggestion for future research is an empirical validation of the model proposed here, in cities of different sizes and geographical contexts, through presenting an inclusive index to measure their performance in each dimension presented. Thus, a quantitative approach and multiple case studies in several cities are suggested. In this way, it is suggested, for example, to determine the weighting coefficients of each dimension in a composite index following the methodology of the OECD [201] to evaluate the 
performance of cities by size, with the appropriate adaptations. Another suggestion is to carry out a comparative study between cities to elaborate a ranking. Finally, it is suggested that later studies could include the construction of a composite index that, in the urban sustainability dimension, includes the sub-dimension of urban design in accordance with Bay [202] and Chermayeff and Tzonis [203].

Author Contributions: M.R. had the initial idea of the manuscript and wrote an original draft, as well as provided the resources for the research and M.F. participated in the formal reviews and supervision.

Funding: This research was not funded.

Acknowledgments: The authors thank the anonymous reviewers for their very helpful comments that contributed to the development of this paper. The authors gratefully acknowledge financial support from FCT and FEDER/COMPETE through grant PEst-C/EGE/UI4007/2013.

Conflicts of Interest: The authors declare no conflict of interest.

\section{References}

1. Cohen, B. What Exactly is A Smart City. Available online: https://www.fastcompany.com/1680538/what-e xactly-is-a-smart-city (accessed on 29 October 2018).

2. Ratten, V. Entrepreneurship, Innovation and Smart Cities; Routledge: Abingdon-on-Thames, UK; New Work, NY, USA, 2017.

3. Neirotti, P.; de Marco, A.; Cagliano, A.C.; Mangano, G.; Scorrano, F. Current trends in smart city initiatives: Some stylised facts. Cites 2014, 38, 25-36. [CrossRef]

4. Albino, V.; Berardi, U.; Dangelico, R.M. Smart Cities: Definitions, Dimensions, Performance, and Initiatives. J. Urban Technol. 2015, 22, 3-21. [CrossRef]

5. Ballas, D. What makes a 'happy city'? Computational Story Lab, 25 February 2013; Volume 32.

6. Tranos, E.; Gertner, D. Smart networked cities? Innov. Eur. J. Soc. Sci. Res. 2012, 25, 175-190. [CrossRef]

7. Amin, N.; Massey, A.; Thrift, D. Cities for the Many not the Few; Policy Press: Bristol, UK, 2000.

8. Hollands, R.G. Will the real smart city please stand up? Intelligent, progressive or entrepreneurial? City 2008, 12, 303-320. [CrossRef]

9. Aurigi, A. Making the Digital City: The Early Shaping of Urban Internet Space; Ashgate Publishing, Ltd.: Farnham, UK, 2005.

10. Lee, J.H.; Phaal, R.; Lee, S.H. An integrated service-device-technology roadmap for smart city development. Technol. Forecast. Soc. Chang. 2013, 80, 286-306. [CrossRef]

11. Romein, J.; Trip, A. Key Elements of Creative City Development: An Assessment of Local Policies in Amsterdam and Rotterdam. In Proceedings of the City Futures' 09, Madrid, Spain, 4-6 June 2009.

12. Florida, R. The Rise of the Creative Class (and How It's Transforming Work, Leisure, Community and Everyday Life); Basic Books: New York, NY, USA, 2002.

13. Florida, R. Cities and the Creative Class; Routledge: Abingdon-on-Thames, UK, 2005.

14. Grant, J.L.; Kronstal, K. The social dynamics of attracting talent in Halifax. Can. Geogr. 2010, 54, 347-365. [CrossRef]

15. Ben Letaifa, S. How to strategize smart cities: Revealing the SMART model. J. Bus. Res. 2015, 68, 1414-1419. [CrossRef]

16. Caragliu, A.; del Bo, C.; Nijkamp, P. Smart cities in Europe. J. Urban Technol. 2011, 18, 65-82. [CrossRef]

17. UNDESA. World Economic and Social Survey 2013: Sustainable Development Challenges; UNDESA: New York, NY, USA, 2013.

18. Pérez-Urrestarazu, L.; Fernández-Cañero, R.; Franco-Salas, A. Vertical Greening Systems and Sustainable Cities. J. Urban Technol. 2015, 22, 65-85. [CrossRef]

19. Musterd, W.J.M.; Ostendorf, S. Creative cultural knowledge cities; Perspectives and planning strategies. Built. Environ. 2004, 30, 189-193. [CrossRef]

20. O'Connor, K.; Shaw, J. What next for the creative city? City Cult. Soc. 2014, 5, 165-170. [CrossRef]

21. Ratiu, D.E. Creative cities and/or sustainable cities: Discourses and practices. City Cult. Soc. 2013, 4, 125-135. [CrossRef]

22. Florea, C.A. Creative and Innovative cities-A new perspective for sustainable development. Netw. Intell. Stud. 2015, III, 49-53. 
23. Cohendet, P.; Zapata, S. Innovation and creativity: Is there economic significance to the creative city? Manag. Int. 2009, 13, 23-26. [CrossRef]

24. Landry, C. The Art of City Making; Routledge: Abingdon-on-Thames, UK, 2006.

25. Girard, P.; Baycan, L.F.; Nijkamp, T. Sustainable City and Creativity: Promoting Creative Urban Initiatives; Ashgate: Farnham, UK, 2011.

26. Malecki, E.J. Cities and regions competing in the global economy: Knowledge and local development policies. Environ. Plan. C Govern. Policy 2007, 25, 638-655. [CrossRef]

27. Pain, K.; van Hamme, G.; Vinciguerra, S.; David, Q. Global networks, cities and economic performance: Observations from an analysis of cities in Europe and the US. Urban Stud. 2015, 53, 1137-1161. [CrossRef]

28. Lee, J.H.; Hancock, M.G.; Hu, M.C. Towards an effective framework for building smart cities: Lessons from Seoul and San Francisco. Technol. Forecast. Soc. Chang. 2014, 89, 80-99. [CrossRef]

29. Bibri, S.E.; Krogstie, J. Smart sustainable cities of the future: An extensive interdisciplinary literature review. Sustain. Cities Soc. 2017, 31, 183-212. [CrossRef]

30. Eduardo, L.; Flores, B.; Teixeira, C. Cidades Sustentáveis e Cidades Inteligentes: Uma Análise dos Rankings Arcadis e European Smart Cities. Available online: http:/ / www.revistas.udesc.br/index.php/reavi/article/ view / 2316419006092017068 (accessed on 29 October 2018). (In Portuguese)

31. Borén, T.; Young, C. Getting creative with the 'creative city'? Towards new perspectives on creativity in urban policy. Int. J. Urban Reg. Res. 2013, 37, 1799-1815. [CrossRef]

32. Priano, F.; Guerra, C. A framework for measuring smart cities. In Proceedings of the 15th Annual International Conference on Digital Government Research, Aguascalientes, Mexico, 18-21 June 2014.

33. Huovila, A.; Penttinen, T.; Airaksinen, M.; Pinto-Seppä, I.; Piira, K.; Penttinen, T. Smart city performance measurement system. In Proceedings of the 41th IAHS World Congress Sustainability Innovation for the Future, Algarve, Portugal, 13-16 September 2016; pp. 1-10.

34. Networked Society City Index. Cities Play Key Role in Sustainable Development. 2016. Available online: www.er icsson.com/assets / local/networked-society/reports / city-index/2016-networked-society-city-index.pdf (accessed on 2 September 2018).

35. European Commission. Cities of Tomorrow-Challenges, Visions, Ways Forward; Publications Office of the European Union: Luxembourg, 2011.

36. Anthopoulos, L. Smart utopia VS smart reality: Learning by experience from 10 smart city cases. Cities 2017, 63, 128-148. [CrossRef]

37. New Economics Foundation (NEF). Five Headline Indicators of National Success-A Clearer Picture of How the UK is Performing; New Economics Foundation: London, UK, 2015.

38. Kourtit, K.; Nijkamp, P.; Steenbruggen, J. The significance of digital data systems for smart city policy. Socioecon. Plan. Sci. 2017, 58, 13-21. [CrossRef]

39. Kourtit, K.; Nijkamp, P.; Franklin, R.S.; Rodríguez-Pose, A. A blueprint for strategic urban research: The urban piazza. Town Plan. Rev. 2014, 85, 97-126. [CrossRef] [PubMed]

40. Lennert, M.; van Hamme, G.; Patris, C. The ESPON 2013 Programme FOCI Future Orientations for Cities Draft Final Report; ESPON: Luxembourg, 2010.

41. Davoudi, S.; Sturzaker, J. Resources, Conservation and Recycling Urban form, policy packaging and sustainable urban metabolism. Resour. Conserv. Recycl. 2017, 120, 55-64. [CrossRef]

42. Camagni, R. Creativity, Culture and Urban Milieux. In Sustainable City and Creativity: Promoting Creative Urban Initiatives; Girard, P., Baycan, L.F., Nijkamp, T., Eds.; Routledge: Abingdon-on-Thames, UK, 2011; pp. 183-189.

43. Saisana, M.; Montalto, V. The Cultural and Creative Cities Monitor (C3 Monitor). Available online: https:/ / www.politico.eu/wp-content/uploads/2017/07/CulturalCreativeCitiesIndex.pdf (accessed on 29 October 2018).

44. Stano, P.M.; Węziak-Białowolska, D. Measuring Cultural and Creative Activities in European Cities: Challenges and Practical Problems with Existing Indices. Creat. Res. J. 2017, 29, 292-303. [CrossRef]

45. Wu, M.C.; Wen, C.T.; Wu, S.H.; Lin, B. The social context of creativity at third places: An exploratory study. Int. J. Manag. Enterp. Dev. 2008, 5, 30. [CrossRef]

46. Giffinger, R.; Fertner, C.; Kramar, H.; Kalasek, R. Pichler-Milanovic. Smart Cities Ranking of European Medium-Sized Cities; Final Report; Vienna University of Technology: Vienna, Austria, 2007.

47. Lazaroiu, G.C.; Roscia, M. Definition methodology for the smart cities model. Energy 2012, 47, 326-332. [CrossRef] 
48. Piro, G.; Cianci, I.; Grieco, L.A.; Boggia, G.; Camarda, P. Information centric services in Smart Cities. J. Syst. Softw. 2014, 88, 169-188. [CrossRef]

49. Paskaleva-Shapira, K.A. E-city Europe: Status, Propositions, and Opportunities. In Proceedings of the International Conference Intelligent Environments, Ulm, Germany, 24-25 September 2007.

50. Addanki, S.C.; Venkataraman, H. Greening the economy: A review of urban sustainability measures for developing new cities. Sustain. Cities Soc. 2017, 32, 1-8. [CrossRef]

51. Ahmad, N.; Mehmood, R. Enterprise systems: Are we ready for future sustainable cities. Supply Chain Manag. Int. J. 2015, 20, 264-283. [CrossRef]

52. Dizdaroglu, D. The Role of Indicator-Based Sustainability Assessment in Policy and the Decision-Making Process: A Review and Outlook. Sustainability 2017, 9, 1018. [CrossRef]

53. Skrede, J. What may culture contribute to urban sustainability? Critical reflections on the uses of culture in urban development in Oslo and beyond. J. Urban 2016, 9, 408-425. [CrossRef]

54. United Nations. An Integrated Strategy for Sustainable Cities; No. 40; United Nations: New York, NY, USA, 2013.

55. Esteban, A.; Ugalde, M.S.; Rodríguez, I.; Altuzarra, A. Territorios Inteligentes: Dimensiones y Experiencias Internacionales; Netbiblio: Bern, Germany, 2008.

56. Pozdniakova, A. smart sustainable cities: The concept. Acta Innov. 2017, 22, 5-19.

57. Scott, A.J. Creative cities: Conceptual issues and policy questions. J. Urban Aff. 2006, 28, 1-17. [CrossRef]

58. Scott, A.J. Capitalismo y Urbanización en una Nueva Clave? University College of Cundinamarca: Fusagasugá, Colombia, 2007; pp. 195-217.

59. Shapiro, J.M. Smart cities: Quality of life, productivity, and the growth effects of human capital. Rev. Econ. Stat. 2006, 88, 324-335. [CrossRef]

60. Mahizhnan, A. Smart cities: The singapore case. Cities 1999, 16, 13-18. [CrossRef]

61. Thuzar, M. Urbanization in southeast Asia: Developing smart cities for the future? Reg. Outlook 2011, 96-100. [CrossRef]

62. Nam, T.; Pardo, T.A. Conceptualizing smart city with dimensions of technology, people, and institutions. In Proceedings of the 12th Annual International Digital Government Research Conference: Digital Government Innovation in Challenging Times, College Park, MD, USA, 12-15 June 2011; p. 282.

63. Barrionuevo, J.M.; Berrone, P.; Costa, J.E.R. Smart cities, sustainable progress: Opportunities for urban development. IESE Insight 2012, 8, 50-57. [CrossRef]

64. Chourabi, H.; Nam, T.; Walker, S.; Gil-Garcia, J.R.; Mellouli, S.; Nahon, K.; Pardo, T.A.; Scholl, H.J. Understanding smart cities: An integrative framework. In Proceedings of the 2012 45th Hawaii International Conference on System Sciences, Maui, HI, USA, 4-7 January 2012; pp. 2289-2297.

65. Eger, J.M. Smart growth, smart cities, and the crisis at the pump a worldwide phenomenon. I-Ways 2009, 32, 47-53.

66. Kourtit, K.; Nijkamp, P. Smart cities in the innovation age. Innovation 2012, 25, 93-95. [CrossRef]

67. Lynch, A.J.; Mosbah, S.M. Improving local measures of sustainability: A study of built-environment indicators in the United States. JCIT 2017, 60, 301-313. [CrossRef]

68. United Nations. Smart Sustainable Cities Indicators; United Nations: New York, NY, USA, 2015.

69. Hartley, J.; Potts, J.; MacDonald, T. The CCI creative city index 2012. Cult. Sci. J. 2012, 5, 138. [CrossRef]

70. Carli, R.; Dotoli, M.; Pellegrino, R. Multi-criteria decision-making for sustainable metropolitan cities assessment. J. Environ. Manage. 2018, 226, 46-61. [CrossRef] [PubMed]

71. Carli, R.; Dotoli, M.; Pellegrino, R.; Ranieri, L. Measuring and managing the smartness of cities: A framework for classifying performance indicators. In Proceedings of the 2013 IEEE International Conference on Systems, Man, and Cybernetics, Manchester, UK, 13-16 October 2013; pp. 1288-1293.

72. Berardi, U. Sustainability assessment of urban communities through rating systems. Environ. Dev. Sustain. 2013, 15, 1573-1591. [CrossRef]

73. Nardo, M.; Saisana, M.; Saltelli, A.; Tarantola, S. Tools for Composite Indicators Building. Available online: http: / / publications.jrc.ec.europa.eu/repository/bitstream/JRC31473/EUR\%2021682\%20EN.pdf (accessed on 31 October 2018).

74. Giampietro, A.; Gamboa, M.; Lobo, G. The Urban Metabolic Pattern: Dynamics and Sustainability. In Sustainable City and Creativity: Promoting Creative Urban Initiatives; Girard, P., Baycan, L.F., Nijkamp, T., Eds.; Routledge: Abingdon-on-Thames, UK, 2011; pp. 323-338. 
75. Gertler, M.S. Creative Cities: What Are They For, How Do They Work, and How Do We Build Them? Available online: https://www.researchgate.net/publication/242098963_Creative_Cities_What_Are_Th ey_for_How_Do_They_Work_and_How_Do_We_Build_Them (accessed on 29 October 2018).

76. Landry, C. The Creative City: A Toolkit for Urban Innovators; Qinghua University Press: Beijing, China, 2000.

77. Bradford, N. Creative Cities Structured Policy Dialogue Backgrounder. Available online: http:/ /www.urba ncenter.utoronto.ca/pdfs/elibrary/CPRN_Creative-Cities-Backgr.pdf (accessed on 31 October 2018).

78. Romero-padilla, Y.; Navarro-jurado, E.; Malvárez-garcía, G.; Navarro-jurado, E.; Malvárez-garcía, G. The potential of international coastal mass tourism destinations to generate creative capital. J. Sustain. Tour. 2017, 24, 574-593. [CrossRef]

79. Kakiuchi, E. Culturally creative cities in Japan: Reality and prospects. City Cult. Soc. 2016, 7, 101-108. [CrossRef]

80. Hospers, G.-J.; Pen, C.-J. A view on creative cities beyond the hype. Creat. Innov. Manag. 2008, 17, $259-270$. [CrossRef]

81. Nelson, R.R.; Winter, S.G. Evolutionary theorizing in economics. J. Econ. Perspect. 2002, 16, 23-46. [CrossRef]

82. Amin, A.; Thrift, N. Cultural-economy and cities. Prog. Hum. Geogr. 2007, 31, 143-161. [CrossRef]

83. Furtado, G.; Alves, S. Cidades criativas em Portugal e o papel da arquitetura: Mais uma estratégia a concertar. Revista Crítica de Ciências Sociais 2012, 99, 125-140. (In Portuguese) [CrossRef]

84. Boden, M.A. The Creative Mind: Myths and Mechanism (Google eBook); Routledge: Abingdon-on-Thames, UK, 2004.

85. Power, A.J.; Scott, D. Culture, creativity, and urban development. In Handbook of Local and Regional Development; Pike, J., Rodríguez-Pose, A., Tomaney, A., Eds.; Routledge: Abingdon-on-Thames, UK, 2011; pp. 162-171.

86. Lazrak, J.; Nijkamp, F.; Rietveld, P.; Rouwendal, P. Cultural heritage and creative cities: An economic evaluation perspective. In Sustainable City and Creativity: Promoting Creative Urban Initiatives; Girard, P., Baycan, L.F., Nijkamp, T., Eds.; Routledge: Abingdon-on-Thames, UK, 2011; pp. 225-243.

87. Pratt, A.C. New media, the new economy and new spaces. Geoforum 2000, 31, 425-436. [CrossRef]

88. Pratt, A.C. Creative cities: The cultural industries and the creative class. Geogr. Ann. Ser. B Hum. Geogr. 2008, 90, 107-117. [CrossRef]

89. Scott, A. The Cultural Economy of Cities: Essays on the Geography of Image-Producing Industries; SAGE Publications: Thousand Oaks, CA, USA, 2000.

90. Bisello, M.; Grilli, A.; Balest, G.; Stellin, J.; Ciolli, G. Co-benefits of Smart and Sustainable Energy District Projects: An Overview of Economic Assessment Methodologies. In Smart and Sustainable Planning for Cities and Regions; Bisello, P., Vettorato, A., Stephens, D., Elisei, R., Eds.; Springer: Berlin/Heidelberg, Germany, 2017; pp. 127-164.

91. He, J. From the New Economy to Creative City. In Creative Industry Districts An Analysis of Dynamics, Networks and Implications on Creative Clusters in Shanghai; He, J., Ed.; Springer: Berlin/Heidelberg, Germany, 2014; pp. 5-42.

92. Carta, M. Culture, communication and cooperation: The three Cs for a proactive creative city. Int. J. Sustain. Dev. 2009, 12, 124-133. [CrossRef]

93. Kong, L. From cultural industries to creative industries and back? Towards clarifying theory and rethinking policy. Inter-Asia Cult. Stud. 2014, 15, 593-607. [CrossRef]

94. Donnell, A.O.; Gilmore, A.; Cummins, D.; Carson, D. The network construct in entrepreneurship research: A review and critique. Manag. Decis. 2001, 39, 749-760. [CrossRef]

95. Parkhe, A.; Wasserman, S.; Ralston, A. New frontiers in network theory development. Acad. Manag. Rev. 2006, 31, 560-568. [CrossRef]

96. Castells, M. The Information Age: Economy, Society, and Culture. Volume I: The Rise of the Network Society. Available online: http://www.urbanisztika.bme.hu/wp-content/uploads/2014/05/manuel_castells_the _rise_of_the_network_societybookfi-org.compressed.pdf (accessed on 29 October 2018).

97. Camagni, R.; Capello, R. The city network paradigm: Theory and empirical evidence. Contrib. Econ. Anal. 2004, $266,495-529$.

98. Capello, R. The city network paradigm: measuring urban network externalities. Urban Stud. 2000, 37, $1925-1945$. [CrossRef]

99. Meijers, E.J.; Burger, M.J. Borrowing Size in Networks of Cities: City Size. Available online: https:/ / onlineli brary.wiley.com/doi/full/10.1111/pirs.12181 (accessed on 31 October 2018).

100. Dijkstra, L.; Garcilazo, E.; Mccann, P. The Economic Performance of European Cities and City Regions: Myths and Realities. Available online: https://www.tandfonline.com/doi/abs/10.1080/09654313.2012.716245 (accessed on 31 October 2018). 
101. David, C.; Peeters, Q.; van Hamme, D.; Vandermotten, G. Is bigger better? Economic performances of European cities 1960-2009. Cities 2013, 35, 237-254. [CrossRef]

102. Schaffers, H.; Komninos, N.; Pallot, M.; Trousse, B. Smart Cities and the Future Internet: Towards Cooperation Frameworks for Open Innovation. Available online: https:/ /link.springer.com/chapter/10.1007/978-3-64220898-0_31 (accessed on 31 October 2018).

103. Jessop, N.L.; Sum, B. An entrepreneurial city in action: Hong Kong's emerging strategies in and for (inter)urban competition. Urban Stud. 2000, 37, 2287-2313. [CrossRef]

104. Meijer, A.; Bolívar, M.P.R. Governing the smart city: A review of the literature on smart urban governance. Int. Rev. Adm. Sci. 2016, 82, 392-408. [CrossRef]

105. European Union. The Cultural and Creative Cities Monitor; European Union: Brussels, Belgium, 2017.

106. Lombardi, P.; Giordano, S.; Farouh, H.; Yousef, W. Modelling the smart city performance. Innovation 2012, 25, 137-149. [CrossRef]

107. Durmaz, B.; Platt, S.; Yigitcanlar, T. Creative, culture tourism and place-making: Istanbul and London film industries. Int. J. Cult. Tour. Hosp. Res. 2010, 4, 198-213. [CrossRef]

108. Bosch, P.; Jongeneel, S.; Rovers, V.; Neumann, H.-M.; Airaksinen, M.; Huovila, A. CITYkeys List of City Indicators. Available online: http:/ / nws.eurocities.eu/MediaShell/media/CITYkeyslistofcityindicators.pdf (accessed on 31 October 2018).

109. Landry, C. Creative City Index; Comfortable or Captivating, Assessment Report of Palmerstone North. Available online: https:/ /www.pncc.govt.nz/media/2096880/creative_city_index_report_web_docum ent_.pdf (accessed on 29 October 2018).

110. Suárez, J.A.G.; Fernández, J.I.P. Creacity, una propuesta de índice para medir la creatividad turística. Aplicación en tres destinos urbano- culturales españoles. Rev. Estud. Reg. 2015, 13, 69-108.

111. Skavronska, I. Creative industries in ukraine: Analysis and prospects of the development. Econ. Sociol. 2017, 10, 87-106. [CrossRef]

112. Joss, S.; Cowley, R.; Tomozeiu, D. Towards the 'ubiquitous eco-city': An analysis of the internationalisation of eco-city policy and practice. Urban Res. Pract. 2013, 6, 54-74. [CrossRef]

113. Panal, G.; Yáñez, C. Industrias culturales en ciudades españolas. Un primer acercamiento. Cultural industries in Spanish cities. A fi rst approach. Rev. Estud. 2012, 94, 71-103.

114. Dhingra, M.; Chattopadhyay, S. Advancing smartness of traditional settlements-case analysis of Indian and Arab old cities. Int. J. Sustain. Built Environ. 2016, 5, 549-563. [CrossRef]

115. United States Environment Protection Agency. Framework for Creating a Smart Growth Economic Development Strategy: A Tool for Small Cities and Towns. Available online: https:/ / www.epa.gov/smartgrowth/framewor k-creating-smart-growth-economic-development-strategy (accessed on 29 October 2018).

116. Lawton, P.; Murphy, E.; Redmond, D. Examining the role of 'creative class' ideas in urban and economic policy formation: The case of Dublin, Ireland. Int. J. Knowl. Based Dev. 2010, 1, 267. [CrossRef]

117. Ryser, J. Planning smart cities ... sustainable, healthy, liveable, creative cities ... or just planning cities? Judith Ryser. Plan. Smart Cities 2014, 8, 447-456.

118. Boulton, L.; Brunn, A.; Devriendt, S.D. Cyberinfrastructures and 'Smart'world Cities: Physical, Human and Soft Infrastructures. International Handbook of Globalization and World Cities. Available online: https:/ / www.elgaronline.com/view/9781848446472.00028.xml (accessed on 29 October 2018).

119. Komninos, N. Intelligent Cities: Innovation, Knowledge Systems, and Digital Spaces; Taylor \& Francis Group: Thames, UK, 2002.

120. Fernandes, R.; Gama, R. A Criatividade Territorial Em Portugal: Dos Indicadores Aos Territórios Criativos. Available online: https:/ / core.ac.uk/download/pdf/19133326.pdf (accessed on 29 October 2018). (In Portuguese)

121. Vanolo, A. The image of the creative city: Some reflections on urban branding in Turin. Cities 2008, 25, 370-382. [CrossRef]

122. Bouk, S.H.; Ahmed, S.H.; Kim, D.; Song, H. Named-Data-Networking-Based ITS for Smart Cities; IEEE: New York, NY, USA, 2017; pp. 105-111.

123. Gouvea, R.; Kapelianis, D.; Kassicieh, S. Technological forecasting \& social change assessing the nexus of sustainability and information \& communications technology. Technol. Forecast. Soc. Chang. 2017, 18, 1-188.

124. Hanclova, J.; Doucek, P.; Fischer, J.; Vltavska, K. Does ICT capital affect economic growth in the EU-15 and EU-12 countries? J. Bus. Econ. Manag. 2014, 16, 387-406. [CrossRef] 
125. Mardikyan, S.; Yıldız, E.; Ordu, M.; Şimşek, B. Examining the global digital divide: A cross-country analysis. Commun. IBIMA 2015, 2015, 1-10. [CrossRef]

126. Batty, M.; Axhausen, K.W.; Giannotti, F.; Pozdnoukhov, A.; Bazzani, A. Smart cities of the future. Eur. Phys. J. Spec. Top. 2012, 518, 481-518. [CrossRef]

127. Odendaal, N. Information and communication technology and local governance: Understanding the difference between cities in developed and emerging economies. Comput. Environ. Urban Syst. 2003, 27, 585-607. [CrossRef]

128. Paskaleva, K. Enabling the smart city: The progress of city e-governance in Europe. Int. J. Innov. Reg. Dev. 2009, 1, 405-422. [CrossRef]

129. Torres, L.; Pina, V.; Acerete, B. E-Governance developments in Eu Cities. Reshaping government relation to citizens. Governance 2006, 19, 277-302. [CrossRef]

130. Finger, M.; Razaghi, M. Conceptualizing “Smart Cities”. In Informatik-Spektrum; Springer: Berlin, German, 2016.

131. Arroub, A.; Zahi, B.; Sabir, E.; Sadik, M. A literature review on Smart Cities: Paradigms, opportunities and open problems. In Proceedings of the 2016 International Conference on Wireless Networks and Mobile Communications (WINCOM), Fez, Morocco, 26-29 October 2016; pp. 180-186.

132. Bibri, S.E.; Krogstie, J. On the social shaping dimensions of smart sustainable cities: A study in science, technology, and society. Sustain. Cities Soc. 2017, 29, 219-246. [CrossRef]

133. Madeira, G.; Guimarães, T.; Mendes, L. Assessing some models for city e-government implementation: A case study. Electron.Gov. Int. J. 2016, 12, 86-105. [CrossRef]

134. Angelidou, M. The role of smart city characteristics in the plans of fifteen cities. J. Urban Technol. 2017, 24, 3-28. [CrossRef]

135. Garau, C.; Balletto, G.; Mundula, L. A critical reflection on smart governance in Italy: Definition and challenges for a sustainable urban regeneration. In Smart and Sustainable Planning for Cities and Regions. SSPCR 2015. Green Energy and Technology; Bisello, A., Vettorato, D., Stephens, R., Elisei, P., Eds.; Springer: Berlin, German, 2017; p. 435.

136. Bloom Consulting. Portugal consultingcity brand ranking 2016-Municípios Portugueses. Bloom consult. Ctries. Reg. Cities 2017, 3, 1-56.

137. C. Indicator and S. Indicator. ISO 37120 Indicators. Available online: https://share.ansi.org/ANSI\%20Netw ork \%20on\%20Smart\%20and\%20Sustainable\%20Cities/ISO+37120-2014_preview_final_v2.pdf (accessed on 31 October 2018).

138. Ernst \& Young. Rapporto Smart City Index. 2016. Available online: www.ey.com/...smart...index-2016/.../2 016-EY-smart-city-index (accessed on 21 July 2018).

139. FPA srl. ICity Rate 2017. Available online: http:/ / www.forumpa.it/smart-city/icity-rate-2017-la-classificadelle-citta-intelligenti-italiane-sesta-edizione2017. (accessed on 29 October 2018).

140. Dodgson, M.; Gann, D. Technological innovation and complex systems in cities. J. Urban Technol. 2011, 18, 101-113. [CrossRef]

141. Nam, T.; Pardo, T.A. Smart city as urban innovation: Focusing on management, policy, and context. In Proceedings of the 5th International Conference on Theory and Practice of Electronic Governance (ICEGOV2011), Tallinn, Estonia, 26-28 September 2011.

142. Klein, V.; Todesco, J. Um Modelo Conceitual Para uso de Big Data E Open Data NAS Smart Cities. Int. J. Knowl. Eng. Manage. 2017, 3, 28-50.

143. Camagni, R.; Capello, R.; Nijkamp, P. Towards sustainable city policy: An economy-environment technology nexus. Ecol. Econ. 1998, 24, 103-118. [CrossRef]

144. Keiner, M.; Schmid, W.A. On the way to Gigapolises: Can global urban development become sustainable? Urban Regeneration and Sustain. 2006, 93, 169-178.

145. Mendes, W. Implementing Social and Environmental Policies in Cities: The Case of Food Policy in Vancouver, Canada. Available online: https:/ / onlinelibrary.wiley.com/doi/full/10.1111/j.1468-2427.2008.00 814.x (accessed on 29 October).

146. Elkington, J. Enter the Triple Bottom Line. The Triple Bottom Line: Does it All Add up. Available online: http:/ / www.johnelkington.com/archive/TBL-elkington-chapter.pdf (accessed on 29 October 2018).

147. Brundtland, G.H. Our Common Future. In Oxford Paperbacks; No. A/42/427; Oxford University Press: Oxford, UK, 1987; p. 400.

148. Wheeler, S.; Beatley, T. The Sustainable Urban Development Reader; Routledge: Abingdon-on-Thames, UK, 2014. 
149. Kondepudi, S. An Overview of Smart Sustainable Cities and the Role of Information and Communication Technologies. Available online: https:/ / www.itu.int/en/ITU-D/Regional-Presence/ArabStates/Docume nts/events/2015/SSC/S3-DrSekharKondepudi.pdf (accessed on 31 October 2018).

150. Cavalcanti, C. Sustentabilidade da Economia: Paradigmas Alternativos de Realização Econômica. Desenvolvimento e Natureza: Estudos para uma Sociedade Sustentável. Available online: https:/ / guilhardes.f iles.wordpress.com/2008/07/ cavalcanti-desenvolvimento-e-natureza.pdf (accessed on 29 October 2018). (In Portuguese)

151. Phearson, T.M.; Pickett, S.T.A.; Grimm, N.B.; Qureshi, S. Advancing Urban Ecology toward a Science of Cities. Bioscience 2016, 66, 198-212. [CrossRef]

152. Hodja, A. Tecnologia, Informação e Atores: Conectando as Partes da Cidade Inteligente. III Simpósio Internacional LAVITS Vigilância, Tecnopolíticas, Territórios. 2015. Available online: http:/ /lavitsrio2015.medialabufrj.net/1 avits-abstract/tecnologia-informacao-e-atores-conectando-as-partes-da-cidade-inteligente/ (accessed on 3 May 2018).

153. Ono, T.; Lida, K.; Yamazaki, S. Achieving sustainable development goals (SDGs) through ICT services. FUJITSU Sci. Tech. J. 2017, 53, 17-22.

154. Jain, H. Green ICT Organizational Implementations and Workplace Relationships; IGI Global: Hershey, PA, USA, 2011; pp. $1228-1230$.

155. Porras, B.; Palacin-Silva, J.; Drögehorn, M.; Penzenstadler, O. Developing a model for evaluation of sustainability perspectives and effects in ICT projects. In Proceedings of the International Sustainable Ecological Engineering Design for Society (SEEDS) Conference, Leeds, UK, 13-14 September 2017.

156. European Comission. An EU Action Plan for the Circular Economy. Available online: https:/ / ec.europa.eu /growth/industry/sustainability/circular-economy_en (accessed on 29 October 2018).

157. Staniškis, J.K. Sustainable consumption and production: How to make it possible. Clean Technol. Environ. Policy 2012, 14, 1015-1022.

158. Lilja, R.K. Policy instruments for promoting material efficiency: Case of Finland. Clean Technol. Environ. Policy 2015, 17, 2029-2040.

159. Ghisellini, P.; Cialani, C.; Ulgiati, S. A review on circular economy: The expected transition to a balanced interplay of environmental and economic systems. J. Clean. Prod. 2015, 114, 11-32. [CrossRef]

160. Alwan, P.; Jones, Z.; Holgate, P. Strategic sustainable development in the UK construction industry, through the framework for strategic sustainable development, using building information modelling. J. Clean. Prod. 2017, 140, 349-358. [CrossRef]

161. McManus, P. Contested terrains: Politics, stories and discourses of sustainability. Env. Polit. 1996, 5, 48-73. [CrossRef]

162. Molnar, D.; Morgan, D.; Bell, A. Defining Sustainability, Sustainable Development and Sustainable Communities: A working paper for the Sustainable Toronto Project. Available online: https:/ /www.google.c om.tw $/$ url?sa=t\&rct=j\&q=\&esrc=s\&source=web\&cd=1\&ved=2ahUKEwilje3xnLDeAhUKdt4KHTs0DEcQ FjAAegQICBAC\&url=http $\% 3 \mathrm{~A} \% 2 \mathrm{~F} \% 2$ Fsites.utoronto.ca $\% 2$ Fenvstudy $\% 2$ Fsustainabletoronto $\% 2$ Fresource s\%2FSustainableTorontoDefinitionsPaper-FinalDraft.doc\&usg=AOvVaw3FreTQcwerwSBvQ5-MbUcM (accessed on 31 October 2018).

163. Bibri, S.E. The Shaping of Ambient Intelligence and the Internet of Things; Springer: Berlin, German, 2015; Volume 10.

164. Banks, M.; Lovatt, A.; O'Connor, J.; Rao, C. Risk and trust in the cultural industries. Geoforum 2000, 31, $453-464$. [CrossRef]

165. Asheim, B.; Coenen, L.; Vang, J. Face-to-face, buzz, and knowledge bases: Sociospatial implications for learning, innovation, and innovation policy. Environ. Plan. C Gov. Policy 2007, 25, 655-670. [CrossRef]

166. Vinodrai, T. Reproducing Toronto's design ecology: Career paths, intermediaries, and local labor markets. Econ. Geogr. 2006, 82, 237-263. [CrossRef]

167. Siegel, K. Can Regional Cooperation Promote Sustainable Development? In The Palgrave Handbook of International Development; Grugel, J., Hammett, D., Eds.; Palgrave Macmillan: Basingstoke, UK, 2016; pp. 713-730.

168. Sharma, A.; Kearins, K. Interorganizational collaboration for regional sustainability: What happens when organizational representatives come together? J. Appl. Behav. Sci. 2011, 47, 168-203. [CrossRef]

169. Wey, W.; Hsu, J. New urbanism and smart growth: Toward achieving a smart national Taipei University district. Habitat Int. 2014, 42, 164-174. [CrossRef] 
170. Funk, J.L. IT and sustainability: New strategies for reducing carbon emissions and resource usage in transportation. Telecomm. Policy 2015, 39, 861-874. [CrossRef]

171. Wang, Y.; Chen, Y.; Benitez-Amado, J. How information technology influences environmental performance: Empirical evidence from China. Int. J. Inf. Manag. 2015, 35, 160-170. [CrossRef]

172. Baycan, T. Creative cities: Context and perspectives. In Sustainable City and Creativity: Promoting Creative Urban Initiatives; Girard, P., Baycan, L.F., Nijkamp, T., Eds.; Routledge: Abingdon-on-Thames, UK, 2011; p. 15.

173. Girard, L.F. Creativity and the Human Sustainable City: Principles and Approaches for Nurturing City Resilience. In Sustainable City and Creativity: Promoting Creative Urban Initiatives. Available online: https: / www.taylorfr ancis.com/books/e/9781317047957/chapters/10.4324\%2F9781315611464-13 (accessed on 29 October 2018).

174. Forte, F. City Design, Creativity, Sustainability. In Sustainable City and Creativity: Promoting Creative Urban Initiatives; Girard, P., Baycan, L.F., Nijkamp, T., Eds.; Routledge: Abingdon-on-Thames, UK, 2011; pp. 289-321.

175. Wu, S.J.; Raghupathi, W. The Strategic Association between Information and Communication Technologies and Sustainability: A Country-Level Study. J. Glob. Inf. Manag. 2015, 23, 92-115. [CrossRef]

176. Bifulco, F.; Tregua, M.; Amitrano, C.C.; D'Auria, A. ICT and sustainability in smart cities management. Int. J. Public Sect. Manag. 2016, 29, 132-147. [CrossRef]

177. Pflieger, G.; Rozenblat, C. Urban networks and network theory: The city as the connector of multiple networks. Urban Stud. 2010, 47, 2723-2735. [CrossRef]

178. Cohen, B.; Muñoz, P. Toward a Theory of Purpose-Driven Urban Entrepreneurship. Organ. Environ. 2015, 28, 264-285. [CrossRef]

179. Osorio, A.E.; Cordero, J.A. Entrepreneurship Education in Practice: The Development of a Hybrid Training Model in an Urban Environment. Available online: https:/ /www.emeraldinsight.com/doi/abs/10.1108/S 1048-473620140000024007 (accessed on 31 October 2018).

180. Snow, C.C.; Håkonsson, D.D.; Obel, B. A smart city is a collaborative community: Lessons from smart aarhus. Calif. Manag. Rev. 2016, 59, 92-108. [CrossRef]

181. Batten, J. Sustainable Cities Index 2016. Available online: https:/ / www.arcadis.com/en/middle-east/ our-p erspectives /2016/09/sustainable-cities-index-2016/ (accessed on 29 October 2018).

182. Devol, R.; Ratnatunga, M.; Bedroussian, A. 2016 Best-Performing Cities. Available online: https://assets1c .milkeninstitute.org/assets/Publication/ResearchReport/PDF/BPC-AsiaProof3Aug22.pdf (accessed on 29 October 2018).

183. Adnan, Y.M.; Hamzah, H.; Alias, A. An Initiatives-Based Framework for Assessing Smart City. Available online: https:/ / www.researchgate.net/publication/309955026_An_initiatives-based_framewor k_for_assessing_smart_city (accessed on 29 October 2018).

184. Trivellato, B. How Can 'Smart' Also Be Socially Sustainable? Insights from the Case of Milan. Eur. Urban Reg. Stud. 2016, 24, 337-351. [CrossRef]

185. Ligorio, V. New Economic Development Pattern: From a Linear to a Circular Economy, a Challenge for EU'S Economy. Available online: https: / $/$ www.google.com.tw / url?sa=t\&rct=j\&q=\&esrc=s\&source=web\&cd=1 \&ved=2ahUKEwjulLOWnbDeAhUVF4gKHUSnCasQFjAAegQICRAC\&url=http\%3A\%2F\%2Firbis-nbuv .gov.ua\%2Fcgi-bin\%2Firbis_nbuv\%2Fcgiirbis_64.exe\%3FC21COM\%3D2\%26I21DBN\%3DUJRN\%26P21D BN\%3DUJRN\%26IMAGE_FILE_DOWNLOAD\%3D1\%26Image_file_name\%3DPDF\%2Fmnj_2017_1\%2528 2\%2529_7.pdf\&usg=AOvVaw3DtJUMxHdGSRmREhvbc4FO (accessed on 31 October 2018).

186. Smol, M.; Kulczycka, J.; Avdiushchenko, A. Circular economy indicators in relation to eco-innovation in European regions. Clean Technol. Environ. Policy 2017, 19, 669-678.

187. Artmann, M.; Kohler, M.; Meinel, G.; Gan, J.; Ioja, I. How Smart Growth and Green Infrastructure Can Mutually Support Each Other-A Conceptual Framework for Compact and Green Cities. Available online: https:/ / www.sciencedirect.com/science/article/pii/S1470160X17304144 (accessed on 31 October 2018).

188. Suzuki, H.; Dastur, A.; Moffatt, S.; Yabuki, N.; Maruyama, H. Eco2 Cities Ecological Cities as Economic Cities; Work Bank: Washington, DC, USA, 2010.

189. Putnam, R.D. Bowling Alone: The Collapse and Revival of American Community; Simon \& Schuster: New York, NY, USA, 2000.

190. Gülümser, P.; Baycan-Levent, A.A.; Nijkamp, T. Measuring regional creative capacity: A literature review for rural-specific approaches. Eur. Plan. Stud. 2010, 18, 545-563. [CrossRef] 
191. Mayer, H.; Knox, P. Small-town sustainability: Prospects in the second modernity. Eur. Plan. Stud. 2010, 18, 1545-1565. [CrossRef]

192. Caragliu, A.; Del, C.F.; Kourtit, K.; Nijkamp, P. The Winner Takes it All: Forward-Looking Cities and Urban Innovation. Available online: https:/ /link.springer.com/article/10.1007/s00168-015-0734-5 (accessed on 31 October 2018).

193. Freire-gibb, L.C.; Nielsen, K. Entrepreneurship within urban and rural areas: Creative people and social networks. Reg. Stud. 2014, 48, 139-153. [CrossRef]

194. Lorenzen, M.; Andersen, K.V. Different creative cities: Exploring Danish data to adapt the creative class argument to small welfare economies. Creat. Ind. J. 2011, 4, 123-136. [CrossRef]

195. Rehák, Š. Creative class and creative cities. Theoretical concept and its limits. Sociologia 2014, 46, 599-619.

196. Rastghalam, M.; Seidaiy, E.; Nouri, H. The creative village approach as a tool for creating village futures. J. Futur. Stud. 2017, 21, 35-48.

197. Flew, T. Creative suburbia: Rethinking urban cultural policy-The Australian case. Int. J. Cult. Stud. 2012, 15, 231-246. [CrossRef]

198. Grodach, C. Cultural economy planning in creative cities: Discourse and practice. Int. J. Urban Reg. Res. 2013, 37, 1747-1765. [CrossRef]

199. Chang, D.L.; Sabatini-Marques, J.; Costa, E.M.D.; Selig, P.M.; Tan, Y. Knowledge-based, smart and sustainable cities: A provocation for a conceptual framework. J. Open Innov. Technol. Mark. Complex. 2018, 4, 5-199. [CrossRef]

200. Dixon, B.S.; Irshad, H.; Pankratz, D.M.; Bornstein, J. The Deloitte City Mobility Index Gauging global readiness for the future of mobility. Available online: https:/ / www2.deloitte.com/content/dam/insights/us/articles/433 1_Deloitte-City-Mobility-Index/4331_city-mobility-index_OVERVIEW.pdf (accessed on 29 October 2018).

201. OECD. Handbook on Constructing Composite Indicators: Methodology and Userguide; OECD: Paris, France, 2008.

202. Bay, J.H. Towards a fourth ecology: Social and environmental sustainability with architecture and urban design. J. Green Build. 2010, 5, 176-197. [CrossRef]

203. Chermayeff, S.; Tzonis, A. Shape of Community: Realization of Human Potential. Available online: https: / / archive.org/details/shapeofcommunity00cher (accessed on 29 October 2018).

(C) 2018 by the authors. Licensee MDPI, Basel, Switzerland. This article is an open access article distributed under the terms and conditions of the Creative Commons Attribution (CC BY) license (http:/ / creativecommons.org/licenses/by/4.0/). 